\title{
WOMEN REPRESENTATION AND RURAL DEVELOPMENT THROUGH PANCHAYATI RAJ SYSTEM IN INDIA- EMERGING TRENDS AND CHALLENGES
}

\author{
Dr. Sanjeev.C. Shirpurkar \\ Head- Dept. Of Political- Science, \\ S.K. Porwal Arts, Science \& Comm, \\ College, Kamptee, Dist-Nagpur, \\ Maharashtra,India
}

Article DOI: https://doi.org/10.36713/epra5490

\begin{abstract}
In our country, it has been an ancient and rich tradition of democratic decentralization through Panchayati institutions. Today, the independent India has completed 25 years on the path of democratic decentralization through the Panchayat Raj Act. During this period, more than 20 states have increased the number of seats reserved for women from $33 \%$ to 50\%. In terms of number of women representatives -Jharkhand is on top in states like Rajasthan, Uttarakhand and Chhattisgarh, while Mizoram is at the bottom in this list. During the period of these 25 years, some new trends have emerged in Panchayati institutions like-Conversion of elite politics into mass politics, decline the concept of sarpanch pati, three-tier pressure on women in a three-tier Panchayati system, conflict status regarding the exercise of political rights, increase in percentage of women representatives and their political awareness, different role and different work culture of women representatives in urban and rural areas, efforts for economic self-reliance through self-help groups etc. .In this era of information revolution in $21^{\text {st }}$ century, these women leaders will have to be technically equipped for the practical implementation of transparent schemes like e-governance and m-governance.Today,panchayati institutions are being entrusted with the important responsibility of connecting people through various schemes related to rural India like "Make in India" and "Digital India". In such a situation, the success of the scheme like Digital Literacy Mission, Ayushyaman Bharat Yojana, Jal shakti Abhiyan, single use plastic ban and e-market plus depend to some extent on the working capacity of these representatives occupying more than half of the Panchayati posts. We can hope that maximum governance and minimum government based our Panchayati system will create immense possibilities in the female leadership, which will change the picture of rural India in the near future, it will also change destiny.

KEYWORDS- Panchayati Raj, Rural Development, Decentralization, Political Awareness, Information Technology, E-Panchayat, E-Governance,Women's Reservation.
\end{abstract}

\section{INTRODUCTION}

It is an absolute privilege of Indians that we live in the world's largest democratic nation. The sucess, importance and purity of any democratic nation depends on the fact that dominion power is vested in maximum number of people, the dominance of this dominating power should be more decentralized, expansion or transfer - Panchayati raj system is certainly an exemplary and praiseworthy endeavor in this direction. This system not only creates a democratic character among the people and people representatives, but also makes them capable of performing important roles at higher level in democratic system of India. In fact, India is a democratic nation as well as the village-nation. More than $70 \%$ of India's population lives in villages and panchayats have been the basis of the socioeconomic and political system of rural India.

\section{REVIEW OF LITERATURE}

There is a rich tradition of Panchayati raj system and institutions in India. The administration was divided into two parts -"PUR" and "JANPAD" during the Ramayana period. In this period, words like "Gram","Jayaraman "Ghosh"were the symbol of decentralization of power. It is also mentioned in the chapter called "Shantiparva"that the smallest unit of governance was the village. In "Manusmriti"decentralization of power, self-government and village administration were discussed. Even in the 
Vedic era, organizations called "Sabha and Samiti" related to local self-government institutions existed. Many republics existed under the monarchy in the Gupta period and Chandragupt Maurya gave priority to decentralization of power. In the Mughal period, Patwari and Mahajan used to conduct the work of local institutions. In British period Panchayats existed but their influence was very less.

"According to the recommendations of Balwant Rai Mehta committee in independent India, the three tier Panchayati raj system was introduced from Nagaur (Rajasthan)on 2nd october1959"(1). After this, panchayat acts were passed by different states for their respective states. From time to time, several committees were set up by the central government regarding the Panchayati raj system. Adil Ali committee (1964) focused on "Gram--Sabha", the Santhanam committee (1965) recommended the representation of scheduled castes, scheduled tribes \& women and also suggest to increase in Panchayati rights. Public participation was supported by Ashok Mehta and Rao committee.Lakshmimal singhvi committee (1986) was supported to free and fair election of panchayats.in1989, during the period of former prime-minister late Rajiv Gandhi an attempt was made to give constitutional form to Panchayati institutions through 64th constitutional amendment, but in the absence of majority in Rajya Sabha ,this effort was not successful.Overall,panchayati institutions remain part of the Directive Principles of state policy till 1992.Finally, in december1992,the 73rd constitutional amendment act was passed by the Lok-Sabha and Rajya-Sabha ,and these institutions were given constitutional recognition. After the Gazette notification on 24th April 1993,33\%seats were reserved for women at every level of the three tier Panchayati raj system and it was mention that the presence of one third women representatives was also necessary for quorum in the "Gram-Sabha'.

\section{OBJECTIVES OF RESEARCH PAPER}

The following two objectives have been set for the detailed analysis of this research title-

1) Analyze increasing female participation, emerging new trends and increasing challenges in Panchayati raj institutions,

2) Provide suggestions for effective solutions to these challenges.

\section{RESEARCH-METHODOLOGY}

The research paper is purely based on secondary data. For the analysis of the research topic various books, journals and literature available on the official website have been studied. Historical, descriptive and analytical method has been used for the analysis of various facts.

\section{HYPOTHESIS}

Regarding this research paper, it has been determined that-"The meaningful role of women in Panchayati institutions can change the destiny of rural development".

\section{ANALYSIS OF RESEARCH PAPER}

Under Democratic decentralization, Panchayati institutions can play the most powerful role in the overall development of rural India.Today,we have completed 25 years on the democratic path through Panchayati institutuons.During this period, "the number of seats reserved for women was increased from 33\% to 50\% in many states'(2)."According to the report of the ministry of Panchayati raj,50\% seats were reserved for women in panchayats in 20 states like-AndhraPradesh, Bihar, Chhattisgarh, Gujrat, Himanchalpradesh, Jharkhand, Karnataka ,Kerala, Madhya Pradesh, Maharashtra, Orissa, Punjab, Rajasthan, Sikkim, Tramlined, Telangana, Tripura, Uttarakhand and West-Bengal"(3).

The following table shows the number of women representatives and their percentage of representation in three-tier Panchayati institutions.

Table-1

ELECTED WOMEN,S REPRESENTATION

\begin{tabular}{|c|c|c|c|c|c|c|}
\hline Serono. & States & $\begin{array}{c}\text { Gram } \\
\text { Panchayat }\end{array}$ & $\begin{array}{c}\text { Block } \\
\text { Panchayat }\end{array}$ & $\begin{array}{c}\text { District } \\
\text { Panchayat }\end{array}$ & Total & $\begin{array}{c}\text { In } \\
\text { Percentage }\end{array}$ \\
\hline 1 & Andra Pradesh & 71996 & 5699 & 330 & 7805 & 50 \\
\hline 2 & $\begin{array}{c}\text { Arunachal } \\
\text { Pradesh }\end{array}$ & 2966 & 625 & 67 & 3658 & 38.99 \\
\hline 3 & Assam & 12100 & 1100 & 210 & 13410 & 50 \\
\hline 4 & Bihar & 51998 & 5341 & 548 & 57887 & 45.44 \\
\hline 5 & Chhattisgarh & 91469 & 1595 & 223 & 93287 & 54.78 \\
\hline 6 & Gujrat & 68880 & 2582 & 526 & 71988 & 49.99 \\
\hline 7 & Haryana & 28060 & 1258 & 181 & 29499 & 42.12 \\
\hline 8 & $\begin{array}{c}\text { Himachal } \\
\text { Pradesh }\end{array}$ & 13409 & 882 & 127 & 14398 & 50.13 \\
\hline
\end{tabular}


ISSN (Online): 2455-3662

EPRA International Journal of Multidisciplinary Research (IJMR) - Peer Reviewed Journal

Volume: 6 | Issue: 10 | October 2020 || Journal DOI: 10.36713/epra2013 || SJIF Impact Factor: 7.032 ||ISI Value: 1.188

\begin{tabular}{|c|c|c|c|c|c|c|}
\hline 9 & $\begin{array}{l}\text { Jammu \& } \\
\text { Kashmir }\end{array}$ & 11169 & - & - & 11169 & 33 \\
\hline 10 & Jharkhand & 27664 & 2812 & 281 & 30757 & 50.60 \\
\hline 11 & Karnataka & 48335 & 2018 & 539 & 50892 & 48.48 \\
\hline 12 & $\begin{array}{l}\text { Madhya } \\
\text { Pradesh }\end{array}$ & 192669 & 3395 & 426 & 196490 & 50 \\
\hline 13 & Maharashtra & 118496 & 1989 & 1005 & 121490 & 50.60 \\
\hline 14 & Manipur & 836 & 0 & 32 & 868 & 50.38 \\
\hline 15 & Mizoram & 828 & - & - & 828 & 23.64 \\
\hline 16 & Odisha & 49840 & 3273 & 438 & 53551 & 49.82 \\
\hline 17 & Punjab & 31373 & 910 & 110 & 32393 & 33.33 \\
\hline 18 & Rajasthan & 66823 & 3118 & 586 & 70527 & 56.49 \\
\hline 19 & Sikkim & 493 & - & 55 & 548 & 50 \\
\hline 20 & Tamilnadu & 37310 & 2426 & 239 & 39975 & 33.99 \\
\hline 21 & Tripura & 2760 & 192 & 54 & 3006 & 45.23 \\
\hline 22 & Telangana & 48267 & 3249 & 219 & 51735 & 50 \\
\hline 23 & Uttarakhand & 34106 & 1633 & 218 & 35957 & 55.66 \\
\hline 24 & Uttar Pradesh & 246038 & 25664 & 1031 & 272733 & 33 \\
\hline 25 & West Bengal & 24991 & 4743 & 423 & 30157 & 50.77 \\
\hline 26 & $\begin{array}{c}\text { Dadar nagar } \\
\text { haveli }\end{array}$ & 43 & - & 04 & 47 & 34.56 \\
\hline 27 & Daman \& diu & 82 & - & 10 & 92 & 53.49 \\
\hline 28 & Goa & 499 & - & 17 & 516 & 32.99 \\
\hline 29 & Chandigarh & 49 & 06 & 03 & 58 & 34.32 \\
\hline 30 & Lakshadweep & 32 & - & 09 & 41 & 37.27 \\
\hline 31 & $\begin{array}{c}\text { Andaman } \\
\text { nicobar }\end{array}$ & 262 & 28 & 12 & 302 & 35.20 \\
\hline & Total & 1292203 & 75620 & 8091 & 1375914 & 44.37 Avg. \\
\hline
\end{tabular}

Sourse-MoPR compilation as on 27-03-2018

It is clear from the study and analysis of the above table that Rajasthan (56.49\%), the leading state in terms of female representation, while Uttarakhand(55.6\%) and Chhattisgarh(54.78\%)in second and third position. Similarly,there are about 12 states \& Union territories where woman have representation in about half or a few more places in Panchayati institutions. According to this table, women have the lowest $23.64 \%$ representation in Panchayati institutions of Mizoram.Similarly,there are 12 states where women representation is more than $50 \%$ in all level of three-tier Panchayati institutions.It is also worth mentioning here that on an average, women hold $44.37 \%$ seats in these institutions at all level.

Emerging new trends regarding female representation in Panchayati raj system -

The general trends emerging in relation to the status and role of women as a result of increasing women's reservation in Panchayati institutions are as follows1) Conversion of elite politics into mass politics - It has been observed that, in the early years of the implementation of this Panchayati act that women of ordinary families were not getting adequate representation in the post reserved for them. Only wives, daughters or close relatives of men who dominated politics were entering in politics by seeking candidacy in the elections, but this situation has changed a lot in the present decade.Today,women from all the families of all classes are also victorious in elections, playing an influential role in these three-tier Panchayati institutions. Now it can be said that the elite culture of politics has been metamorphosed in to mass culture of politics.

2) Decline of the concept of sarpanch husband(pati) There is enough truth in the fact that in the early decade most women did not want to enter in politics voluntarily despite $50 \%$ seats being reserved, but if they were given candidature, patidev worked hard to make them win the election and as soon as the wife became sarpanch , he himself started to play the role of executive sarpanch and his wife elected by people was seen in the role of rubber stamp, it seemed that women reservation has become a mockery but in the last few years it is being seen that Three women not only winning the election on her own strength, but also showing her skill in the decision making process.

3) Three-tier pressure on women in a three-tier Panchayati system - There can be no two opinions that there is family and social pressure on women before getting elected in Panchayati institutions, but after being elected, political pressure also increases 
on them ,that is, women in three- tier Panchayati institutions have to face three-tier pressure. Sometime these pressures have the opposite effects on their work efficiency, political participation and decision-making ability.

4) Even mixed status with respect to exercise of political rights- Women representatives who have knowledge of their rights and duties, adequate knowledge of government policies and schemes seem to be exercising their political rights very well, but sometimes the mobilization of mens, family pressure and responsibilities, social criticism, financial difficulties due to lack of financial management skills are the major problems facing by these representatives in the use of political powers or rights, that is, mixed situation can be seem in the use of political powers.

5) Increasing political awareness and percentage of women representatives-

Undoubtedly there has been a huge increase in female representation and awareness in the last 25 years and the condition and direction of this growth has also been generally positive, but the rural environment is not left untouched by money power, muscle power and man power. In such a situation, it is not easy for women to stand in the elections on their own strength, despite all these challenges increase in female representations continuing and as a result of their efforts, social and political awareness is being increased day by day in the villages.

6) The Role Of women representatives in urban and rural areas varies-

If the female representative is highly educated, economic vision is self-sufficient, she has grown up in cities or nearby towns, then she seems to play a creative role in rural development. The elected female representative of remote and inaccessible areas (Except for a few exceptions) can neither take concrete decisions, sometimes they are unable to present their ideas properly among the people, even in the decision-making process, their role is negligible.

7) Efforts for Economic self-sufficiency through selfhelp groups-

Today, self-help groups have been formed at almost every level of panchayats and especially women led Panchayati institutions have made rural women selfreliant to a large extent by connecting them with rural industries and discharging a strong role for rural development by encouraging each and every one.

8) Increasing influence of slogans on rural masses-

In the same way, slogans like-" Tan $\mathrm{Ki}$ safai-Man Ki safai", "Saf Safai-Sabko bhai".Na Gandgi karenge-Na karne denge"," Mahila padhegiVikas gadhegi",Gadi wala aaya ghar se kachra nikal"influenced the male and female representatives as well as the public opinion and also influence the work behavior and inspired them to move on the development path in a clean and healthy environment.

\section{Examples of notable roles of women representatives in Panchayati institutions-}

Undoubtedly, some women representatives have surprised everyone by performing very excellently through the Panchayati institutions, of which some prominent examples are being presented here-

1) Miss Chavis Ranavat (Village-Soda,DistrictTonk,Rajasthan)

this women sarpanch has achieved the heights of development by constructing water supply centers, solar energy centers, roads and toilets and setting up banks in her village.

2) Miss Aarti Devi (District-Ganjam,Orissa)-

She has the distinction of being the youngest sarpanch of the country, resigned from the post of bank officer and took up the task of rural development and succeeded in providing 100\% literacy to her village.

3) Miss Meena Bahan (District-vyara,Gujrat)-

She has the distinction of being the first women sarpanch of this district. She established a self-help group and encouraged strong female participation in it and made most of women of her village financially independent.

4) Vijaynagaram district-

In this district, "the goal was to construct 10,000 toilets in 100 hours under the leadership of the district collector, but 10449 toilets were constructed, in this work female and male Panchayati representatives of this district, as well as UNESCO activists and voluntary organizations discharged an important role"(4).

Make in India Mission and the changing role of Panchayati representatives-

Just as the 20th century is known for drastic changes in the field of gender revolution, i.e. gender equality, in the same way the 21 st century is known for the massive change in the field of information revolution. Today we live in the age of EGovernance \& M-Governance. To ensure administrative transparency, these elected representatives should be technically equipped then they play an important role to achieve the goals of make in india.Gradually,along with the concept of EGovernance and M-Governance, the concept of EPanchayat also seems to be taking shape.Today,all the schemes related to rural development are being entrusted to the Panchayati institutions to make them accessible to the people through Digital India. In the changing environment, meaningful role of women representatives is expected in various programs for rural development such as-

\section{1) Digital Literacy Mission and Panchayat-}

According to the report of the United Nations, among the deprived sections from the education, 
women constitute the largest share in the world, similarly the level of female education in the world is less than half of the male education. The 2011 census data tells us that male literacy rate is $82 \%$ and female literacy rate is $63.5 \%$.It is less than $55 \%$ in states like uttarpradesh,Rajasthan,Bihar ect.In this context, the National Digital Literacy Mission has been started in 2014.Under this campaign, the target is to make atleast one person from each family to be digitally literate in the selected blocks under the central and state governments in India. "Among 1.3 billion population in India near about $41 \%$ population is connected to Internet connection"(5).In such a situation, the panchayat representatives can have a meaningful and important role in making rural India digital literate and to make various schemes related to rural development accessible to the people and to make active participation in it."Internet based social media is being used by $22 \%$ mobile oweners in India while on an average it is $75 \%$ globally"(6), digitally educating the public community along with the education of syllabus is very important for this purpose. Women representatives have to work simultaneously, only than it will be possible to achieve the goal of digital literacy.

\section{2) Ayushyaman Bharat Yojana and Panchayati Raj-}

This is the largest health security scheme in the world. Under this cashless scheme, "The central government will bear the cost of treatment up to RS 05 Lakhs in government and private hospitals"(7).The benefit of this scheme for the people of the lower strata of the society, such as labour,plumber ect.In Bihar near about 8 Lakhs Golden-Cards have been made through Panchayati institutions and near about 4Lakhs families got benefit from it.The main objective of this scheme is that no sick person gets killed due to lack of money.Panchayati institutions of other states are also playing important role in present and will also play in future.

\section{3) Role of Panchayati institutions in water conservation and management(Jal-shakti Abhiyaan)-}

It is a universal truth that life is possible only on earth in the entire universe and water conservation is necessary for life preservation. According to article 21 of the Indian constitution "pure and clean drinking water is our fundamental right"(8). Approximately $97 \%$ of the worlds water is found in seas, while only $3 \%$ of the water is available under the ground or in rivers and ponds. India is ranked 133 rd in world in terms of water availability per-capita. We have only $4 \%$ of the available water from rain water. The world's largest drinking water scheme is in rural India. Under the "Jal Shakti Abhiyan" a target has been set to deliver water to every households through a pipeline by 2024.In such a situation, it is the responsibility of the panchayat representatives to play an important role in the proper management and distribution of water sources. Only $18.33 \%$ of the households in India could be connected through pipelines for water supply.

4) Restrictions on single use plastics and Panchayati liability-

From 2nd oct.2019, single used plastics has been banned. In this country 1.4-ton plastic is used every year. It is the responsibility of the panchayat representatives to restricts the single used plastic and keep in mind the goal of "Nirmal Gram Yojana".

\section{5) E-Market Plus Scheme and Panchayat-}

Through this scheme, "buyers and sellers can establish direct contact for the sale of rural products and conduct their business without geographical restrictions"(9). It is the responsibility of Panchayati representatives to benefit the people from the advantages of this scheme.

6) Video-Conferencing and Panchayat-

Video-conferring has become an important part of the governments working today. Through this, direct contact can be established between administration and public representatives and in less time and less cost. Each representative can easily find solutions to the problem of their village

\section{CONCLUSION}

This Panchayati system in the form of maximum government, minimum governance, is proving helpful in the establishment of responsible democracy. Under this system, all classes including women are getting ample opportunities for political participation at every level in three tier Panchayati governance. By taking advantage of this opportunity, the women leadership can make invaluable contribution towards the construction of infrastructure like education, health, roads, housing, drinking water, sanitation, environmental protection. In this entire process we should focus our attention on women development as well as the issue of development by women, only than we can realistically achieve the goal of holistic development by real analysis. In this process of the overall development of all classes, we should not forget the preservation of human values, if we maintain harmony in values and development, then only we can build strong family, society, village and the nation and this can change the picture and destiny of rural India.

\section{REFERENCES}

\footnotetext{
1) shodhganga.inflibnet.ac.in/bitstream/10603/193361 19/09_chapter\%.204.pdf(An overview of Panchayati raj system in India).

2) india.gov.in/my-government/constitutionindia/amendment/constitution-india-seventy-thirdamendment-act-1992.

3) http;//www.panchayat.gov.in>reservation-ofwomen-in-pris.
} 
4) "Vijaynagaram $\mathrm{ka} 100$ ghanton me 10,000 shouchalay, banane ka abhiyan" (August,2017,pp 51), "Kurukshetra.(publicationdivision.nic.in).

5) Sharma,Balendu ,(nov.2019),"Digital Saksharata Ki Disha Me Majboot Kadam" "Kurukshetra" ( publicationdivision.nic.in ).

6) counterview.org $>2019 / 10 / 21>$ constraints-ofdigital-literacy-in-rural-india-only-21-3-ofstudents-have-access-to-computers/

7) https://www.pmjay.gov.in

8) Kashyap,Subhash.c(2001)"OurConstitution",publis hed by the Director,National book trust of India,New Delhi,p-133-134.

9) india.gov.in/spotlight/government-e-marketplaceprocurement-made - smart\#tab=tab-1. 